\title{
In vitro studies on antioxidant, hypolipidemic and cytotoxic potential of Parmelia perlata
}

\author{
Hafizur Rahman ${ }^{1}$, Vijaya B ${ }^{1}$, Soumya Ghosh ${ }^{2}$, Geetika Pant ${ }^{1}$, Sibi G ${ }^{1}$ \\ ${ }^{1}$ Department of Biotechnology, Indian Academy Degree College, Centre for Research and Post Graduate Studies, Bangalore, INDIA \\ ${ }^{2}$ Department of Microbiology, Indian Academy Degree College, Centre for Research and Post Graduate Studies, Bangalore, INDIA

\section{Email address:} \\ gsibii@gmail.com (Sibi G.)
}

\section{To cite this article:}

Hafizur Rahman, Vijaya B, Soumya Ghosh, Geetika Pant, Sibi G. In Vitro Studies on Antioxidant, Hypolipidemic and Cytotoxic Potential of Parmelia Perlata. American Journal of Life Sciences. Special Issue: Recent Developments in Health Care through Plants and Microbes. Vol. 2, No. 6-1, 2014, pp. 7-10. doi: 10.11648/j.ajls.s.2014020601.12

\begin{abstract}
New drug preparations of natural origin are in need due to the numerous side effects and resistance development through the continuous and uncontrolled use of synthetic drugs. Lichens are reported to have manifold biological activities and in this study, antioxidant, hypolipidemic and cytotoxic potential of Parmelia perlata were assessed. Methanolic extract of P. perlata was prepared and used in DPPH assay, total phenolic content and total antioxidant potential assays. In vitro anti-cholesterol and cytotoxic assay using HCT 116 cell lines were performed. The results revealed that $P$. perlata contain high phenolic contents and antioxidant potential. Simvastatin was used as standard drug and the extracts demonstrated 48\% anti-cholesterol activity. MTT assay using colon cancer cell lines (HCT 116) produced dose dependent cytotoxic effect with an IC50 value of $202.1 \mu \mathrm{g} \mathrm{ml}^{-1}$.
\end{abstract}

Keywords: Parmelia Perlata, Antioxidant, Anticancer, Anti-Cholesterol, Colon Cancer

\section{Introduction}

Oxidative stress due to elevated levels of free radicals causes cellular and tissue damage that elicit direct or indirect damage to the body. Cancer is one of the main causes of death all over the world. The world health organization (WHO) estimates that 84 million people would die of cancer between 2005 and 2015 [1]. Hyperlipidemia is caused by a diet high in fat, especially saturated fat and cholesterol. Blood lipids are related to the development of coronary heart diseases. Synthetic antioxidants like butylated hydroxyanisole, butylated hydroxytoluene, tertbutylhydroquinone and propyl gallate have been reported to exert toxic effects [2]. New drug preparations of natural origin are in need due to the numerous side effects and resistance development through the continuous and uncontrolled use of synthetic drugs. Bioactive compounds from natural products have beneficial effects without causing undesired side effects. Among the natural origin, lichens are used in many research. Lichens are symbiotic associations between two entirely different types of microorganisms and produce secondary metabolites that have manifold biological activities $[3,4]$.
Studies on the biological properties of lichens reveals the potential of lichens having antioxidant [5-8], antimicrobial [9-11] and cytotoxic $[12,13]$ activities.

Parmelia perlata (Huds.) Ach. (Parmeliaceae), commonly known as stone flower in India is thallus, foliaceous, membranous leaf like horizontally spreading lobes. The thallus is dirty white or grayish brown nearby 5$10 \mathrm{~cm}$ long. It has bitter or saline taste [14]. Parmelia is useful in treating a number of ailments $[15,16]$ and has also been reported to possess antimicrobial [17, 18], antiviral [19], antioxidant [20], antipyretic [21], anticancer [22] and antispasmodic [23] activities. In this study, Parmelia perlata was examined for its antioxidant, anticholesterol and anticancer activities to derive bioactive compounds from natural origin as great promise for biochemical applications and better human health.

\section{Materials and Methods}

\subsection{Plant Material Collection and Extraction}

Dried samples of Parmelia perlata were collected and identified by a Botanist, Bangalore University. The samples were ground into powder and sieved (60 mesh) and about 
$100 \mathrm{~g}$ of was extracted in methanol $(1: 10 \mathrm{w} / \mathrm{v})$ at $25^{\circ} \mathrm{C}$ for 24 hours. The extract was centrifuged at $10,000 \mathrm{rpm}$ for 10 minutes and the supernatant was filtered using Whatman No.1 filter paper and concentrated to dryness under reduced pressure in rotary vacuum evaporator. The final extract was stored in air tight containers at $4^{\circ} \mathrm{C}$ until used.

\subsection{DPPH Assay}

The capacity of the extract to scavenge the stable 2,2'diphenyl-2-picrylhydrazyl (DPPH) free radical was determined according to the method reported by Gyamfi et al., [24]. In brief, $50 \mu \mathrm{l}$ of the methanolic plant extract (100 $\mu \mathrm{g} \mathrm{ml}^{-1}$ ) was mixed with $1.8 \mathrm{ml}$ of $0.5 \mathrm{mM} \mathrm{DPPH}$ in methanol solution. Methanol $(50 \mu \mathrm{l})$ only was used as the experimental control. After $30 \mathrm{~min}$ of incubation at room temperature, the reduction in the number of DPPH free radicals was measured at $517 \mathrm{~nm}$. The percent inhibition was calculated from the following equation:

$$
\text { Inhibition }(\%)=\frac{\left(\text { Control }_{\mathrm{A} 517}-\text { Sample }_{\mathrm{A} 517}\right)}{\text { Control }_{\mathrm{A} 517}} \times 100
$$

\subsection{Determination of Total Phenolic Content}

The amount of total phenolics in the plant extract was determined with Folin-Ciocalteu (FC) reagent [25]. To 200 $\mu \mathrm{l}$ of sample (3 replicates), $1 \mathrm{ml}$ of $1: 2$ dilution of $\mathrm{FC}$ reagent and $800 \mu \mathrm{l}$ of sodium carbonate $(7.5 \% \mathrm{w} / \mathrm{v})$ were added and the resulting mixture was incubated at room temperature for 30 minutes. The absorbance of the sample was measured at $765 \mathrm{~nm}$ using a spectrophotometer and the results were expressed as milligram of gallic acid equivalent per gram of dry weight.

\subsection{Antioxidant Potential Assay}

The Antioxidant potential assay was carried out by phosphomolybdenum reduction assay [26]. To $200 \mu$ l of plant extract, $1 \mathrm{ml}$ of the reagent containing $4 \mathrm{mM}$ ammonium molybdate, $28 \mathrm{mM}$ sodium phosphate and 0.6 $\mathrm{M}$ sulphuric acid were added and the resulting mixture was incubated at $37^{\circ} \mathrm{C}$ for 60 minutes. The absorbance of sample was measured at $695 \mathrm{~nm}$ using a spectrophotometer against blank using methanol. The antioxidant potential activity is expressed as $\mathrm{mg}$ of ascorbic acid equivalent per gram of dry weight.

\subsection{In Vitro Anti-Cholesterol Assay}

The anti-cholesterol assay was carried out as described by Iswantini et al., [27] and Cholesterol Enzymatic Endpoint Method [28]. Cholesterol was dissolved in chloroform until achieving $25 \mathrm{mg} / 10 \mathrm{ml} .10 \mu \mathrm{l}$ of the plant extract (two concentrations) were pipetted into micro titre plate followed by the addition of $2000 \mu \mathrm{l}$ of Randox reagent and $10 \mu \mathrm{l}$ of cholesterol as sample. $20 \mu \mathrm{l}$ of distilled water and $2000 \mu \mathrm{l}$ of Randox reagent were used as blank. Negative control comprised of $20 \mu \mathrm{L}$ cholesterol and $2000 \mu \mathrm{l}$ Randox reagent; standard comprised of $20 \mu \mathrm{l}$ simvastatin and $2000 \mu \mathrm{l}$ Randox reagent. The contents were mixed and incubated for 10 minutes at room temperature. The absorbance was read at $500 \mathrm{~nm}$ in a microplate reader against reagent blank.

\subsection{MTT Assay}

The lichen extracts were tested for in vitro cytotoxicity using HCT-116 cells by 3-(4,5-dimethylthiazol-2-yl)-2,5diphenyltetrazolium bromide (MTT) assay [29]. HCT 116 (70-80\%) confluent cell lines were trypsinized followed by viability checking and centrifugation. In a 96 well plate, $5 \mathrm{x}$ $10^{4}$ cells/ well were seeded and incubated for $24 \mathrm{hrs}$ at $37^{\circ} \mathrm{C}$ in a humidified $5 \% \mathrm{CO}_{2}$ incubator. Plant extracts of varying concentrations ranging from $0-320 \mu \mathrm{g} / \mathrm{ml}$ (two fold variations) in RPMI media without fetal bovine serum (FBS) and antibiotics were incubated for $24 \mathrm{hrs}$. After incubation with plant extracts, the media was removed from the wells and added $100 \mu \mathrm{l} /$ well $(50 \mu \mathrm{g} /$ well $)$ of the MTT (5 mg/10 $\mathrm{ml}$ of MTT in 1x PBS) working solution was added and incubated for 3 to 4 hours. After incubation with MTT reagent, the media was removed from the wells and added $100 \mu \mathrm{l}$ of DMSO to rapidly solubilize the formazan. The absorbance for each well was measured at $590 \mathrm{~nm}$ in a microtitre plate reader and the percentage inhibition was calculated using the formula.

$$
\text { Inhibition }(\%)=\frac{\left(\text { Control }_{\mathrm{A} 590}-\text { Sample }_{\mathrm{A} 590}\right)}{\text { Control }_{\mathrm{A} 590}} \times 100
$$

\section{Results}

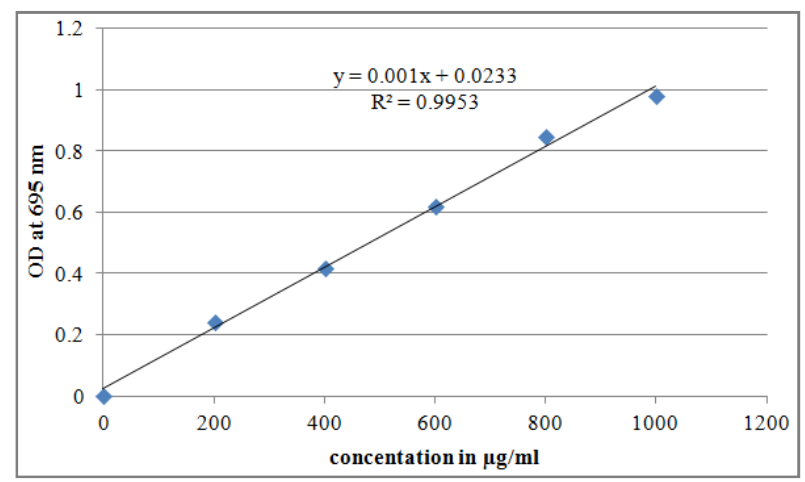

Fig 1. Standard curve for antioxidant potential using ascorbic acid

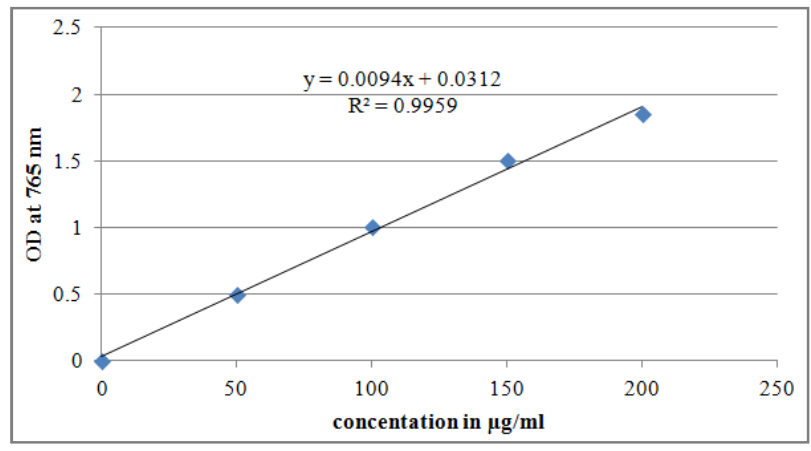

Fig 2. Standard curve for total polyphenols using gallic acid 


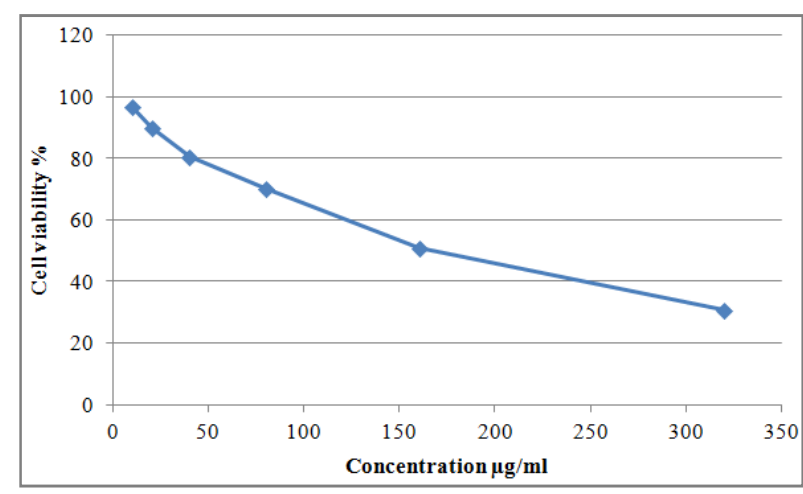

Fig 3. MTT cytotoxic assay using HCT 116 cell lines

Methanolic extracts of Parmelia perlata was prepared by dissolving the concentrated extracts in $98 \%$ methanol and used for biological assays. DPPH assay of methanolic extract of $P$. perlata revealed that $32 \%$ inhibition thereby confirming the presence of antioxidants. Total antioxidant potential was carried out using ascorbic acid (Fig-1) and was determined as $1.3 \mathrm{mg} \mathrm{ml}^{-1}$. The total phenolic content of $P$. perlata was determined spectrophotometrically by the Folin-Ciocalteu method using gallic acid as internal standard (Fig-2) and it was found as $78.4 \mu \mathrm{g} \mathrm{ml}^{-1}$. In vitro anti-cholesterol activity of $P$. perlata was examined using simvastatin as the standard drug for a total half an hour at 10 minutes intervals. The purple colour developed during the reaction was decreased with increasing time and $48 \%$ activity was observed at the end of the reaction whereas $94 \%$ activity was found with the standard drug, simvastatin. Cytotoxic assay using colon cancer cell lines (HCT 116) revealed the antiproliferative activity of $P$. perlata against HCT 116 cell lines. Loss of viability of the dying cells as evidenced by the morphological changes was scrutinized by microscopy. Depending on the concentration, the lichen extract exhibited different levels of cytotoxicity like cell shrinkage, aggregation and cell death with an IC50 value of $202.1 \mu \mathrm{g}$ $\mathrm{ml}^{-1}$ (Fig-3).

\section{Discussion}

Antioxidants quenching the free radicals generated for specific metabolic requirement in the body. Oxidative damage of tissues and biomolecules occur when the levels of free radicals species exceed the level of antioxidant mechanism eventually leading to disease conditions [30]. Medicinal properties of plants have been investigated for their potential antioxidant activities to counteract metabolic disorders [31], Plant extracts and plant-derived antioxidant compounds may potentiate the body's antioxidant defense mechanisms [32]. From results, it may be postulated that Parmelia was able to reduce the stable free radical DPPH to the yellow-colored diphenylpicrylhydrazine exhibiting free radical scavenging activity. Phenolic compounds have potential antioxidant capabilities and in this study a significant level of total phenols were determined from $P$. perlata.
Approximately 4.8 percent of men and women will be diagnosed with colon and rectum cancer at some point during their lifetime and colon cancer represents $8.2 \%$ of all new cancer cases [33]. Anticancer activities of Parmelia species against human melanoma, colon carcinoma and breast cancer cell lines were reported in earlier studies [34, 35]. In this study, HCT 116 cell lines were used to determine the antiproliferative activity of $P$. perlata by MTT assay. The results revealed the cytotoxic activity of the extract in a dose dependent manner. The effect of extract concentration was evidenced by microscopy and IC0 value was found as $202.1 \mu \mathrm{g} \mathrm{ml}^{-1}$. Plant extracts have exhibited anticancer activity against colon cancer in vitro and in vivo [36] and in this study in vitro cytotoxicity of $P$. perlata was determined.

\section{Conclusion}

This study revealed the presence of higher amounts of phenolic compounds in P. perlata and its antioxidant activities. The extract has exhibited significant cytotoxicity against HCT 116 and moderate levels of anti-cholesterol activity. In conclusion, Parmelia derived bioactive compounds hold great promise for biopharmaceutical applications as antioxidant and cytotoxic agents of new formulations for the benefit of human life.

\section{References}

[1] F. Danhier, O. Feron, V. Preat, "To exploit the tumor microenvironment: Passive and active tumor targeting of nanocarriers for anti-cancer drug delivery," J. Control. Release., vol. 148, 35-146, 2010.

[2] W.M. Zhang, B. Li, L. Han, H.D. Zhang, HD, “Antioxidant activities of extracts from areca (Areca catectu L.) flower, husk and seed," Afr J Biotechnol., vol. 8: 3887-3892, 2009.

[3] K. Molnar, E. Farkas, "Current results on biological activities of lichen secondary metabolites: a review," Journal of Biosciences., vol. 65, 157-173, 2010.

[4] T. Mitrovic, S. Stamenkovic, V. Cvetkovic, M. Nikolic, S. Tosic, D. Stojicic, "Lichens as source of versatile bioactive compounds," Biologica Nyssana., vol. 2, 1-6, 2011.

[5] B.C. Behera, N. Verma, A. Sonone, U. Makhija, "Determination of antioxidative potential of lichen Usnea ghattensis in vitro," LWT-Food Sci Technol., vol. 39, 80-85, 2006.

[6] M. Gulluce, A. Aslan, M. Sokmen, F. Sahin, A. Adiquzel, G. Agar, A. Sokmen, "Screening the antioxidant and antimicrobial properties of the lichens Parmelia saxatilis, Platismatia glauca, Ramalina pollinaria, Ramalina polymorpha and Umbilicaria nylanderiana," Phytomedicine., vol. 13, 515-521, 2006.

[7] H.D. Bhattarai, B. Paudel, S.G. Hong, H.K. Lee, J.H. Yim, "Thin layer chromatography analysis of antioxidant constituents of lichens from Antarctica," J Nat Med., vol. $62,481-484,2008$. 
[8] B. Paudel, H.D. Bhattarai, J.S. Lee, S.G. Hong, H.W. Shin, et al. "Antioxidant activity of polar lichens from King George Island (Antarctica)," Polar Biol., vol. 31, 605-608, 2008 .

[9] B.R. Rankovic, M.M. Kosani, T.P. Stanojkovic, "Antioxidant, antimicrobial and anticancer activity of the lichens Cladonia furcata, Lecanora atra and Lecanora muralis," BMC Complement Altern Med., vol. 11, 97, 2011.

[10] A. Karagoz, N. Dogruoz, Z. Zeybek, A. Aslan, "Antibacterial activity of some lichen extracts," J Med Plants Res., vol. 3, 1034-1039, 2009.

[11] M. Kosanic, B. Rankovic, "Antibacterial and antifungal activity of different lichens extracts and lichen acid," Res $J$ Biotechnol., vol. 6, 23-26, 2011.

[12] N.B. Perry, M.H. Benn, N.J. Brennan, E.J. Burgess, G. Ellis, D.J. Galloway, S.D. Lorimer, S. Tangney, "Antimicrobial, antiviral and cytotoxic activity of New Zealand lichens." Lichenologist., vol. 31, 627-636, 1999.

[13] C. Bezivin, S. Tomasi, F. Lohezic-Le Devehat, J. Boustie, J. "Cytotoxic activity of some lichen extracts on murine and human cancer cell lines," Phytomedicine., vol. 10, 499-503, 2003.

[14] K.R. Kiritikar, B.D. Basu, Indian Medicinal plants. $2^{\text {nd }}$ Ed. M.B. Lalit Mohan Basu, Allahabad, vol. 3, 1956.

[15] P. Halama, C.V. Haluwin, "Antifungal activity of lichen extracts and lichenic acids," BioControl, vol. 49, 95-107, 2004.

[16] T. Tay, T.A. Ozdemir, M. Yilmaz, H. Turk, M. Kivanc, "Evaluation of the antimicrobial activity of the acetone extract of the Lichen Ramalina farinacea and its (+)-usnic acid, norstictic acid, and protocetraric acid constituents," Journal of Biosciences, vol. 59, 384-388, 2004.

[17] B. Thippeswamy, N.R. Sushma, K.J. Naveenkumar, "Antimicrobial property of bioactive factor isolated from Parmelia perlata," International Multidisciplinary Research Journal, vol. 2, 1-5, 2012.

[18] G. Sibi, V. Apsara, K. Dhananjaya, K.R. Ravikumar and H. Mallesha, "Phytochemical and antibacterial properties of spices against food borne bacteria with special reference to Parmelia perlata," Global J. Bio-Sci. Biotechnol., vol. 2, 145-149, 2013.

[19] C.O. Esimone, K.C. Ofokansi, M.U. Adikwu, E.C. Ibezim, D.O. Abonyi, G.N. Odaibo, D.O. Olaleye, "In vitro evaluation of the antiviral activity of extracts from the lichen Parmelia perlata (L.) Ach. against three RNA viruses," J Infect Dev Ctries, vol. 1, 315-320, 2007.

[20] S.B. Patil, V.A. Ghadyale, S.S. Taklikar, C.R. Kulkarni, A.U. Arvindekar, "Insulin secretagogue, alpha-glucosidase and antioxidant activity of some selected spices in streptozotocin-induced diabetic rats," Plant Foods Hum Nutr, vol. 66, 85-90, 2011.

[21] K. Muller, "Pharmaceutically relevant metabolites from lichens," Appl. Microbiol Biotechnol., vol. 56, 9-16, 2001.

[22] M.M. Kosanic, B.R. Rankovic, T.P. Stanojkovic, "Antioxidant, antimicrobial and anticancer activities of three Parmelia species," J. Sci. Food Agric., vol. 92, 1909-1916, 2012.
[23] J.A. Correia da Silva, "Action of Parmelia caperata extracts on smooth muscle organs," Arch. Farmacol. Toxicol., vol. 2, 143-152, 1976.

[24] M.A. Gyamfi, M. Yonamine, Y. Aniya, "Free radical scavenging action of medicinal herbs from Ghana Thonningia sanguinea on experimentally induced liver injuries," Gen Pharmacol, vol. 32, 661-667, 1999.

[25] E.A. Ainsworth, K.M. Gillespie, Estimation of total phenolic content and other oxidation substrates in plant tissues using Folin-Ciocalteu reagent. Nature Protocols, vol. 2, 875- 877, 2007.

[26] P. Prieto, M. Pineda, M. Aguilar M, "Spectrophotometric quantitation of antioxidant capacity through the formation of a Phosphomolybdenum Complex: Specific application to the determination of vitamin E," Analytical Biochemistry, vol. 269, 337-341, 1999.

[27] D. Iswantini, D. Nurenda dan, P. Sugita, "Fractionation and characterization of active compounds from Bangle (Zingiber Cassumunar Roxb.) as an activator of the enzyme cholesterol oxidase," Simposium Nasional Kimia Bahan Alam XV. Himpunan Kimia Bahan Alam. Bogor., 2005

[28] Randox Laboratories, 2009. Cholesterol (Chol) enzymatic endpoint method manual. Available online.

[29] S.P.M. Crouch, R. Kozlowski, K.J. Slater, J. Fletcher, "The use of ATP bioluminescence as a measure of cell proliferation and cytotoxicity". J. Immunol. Methods vol. $160,81-88,1993$.

[30] J.M.C. Gutteridge, "Free radicals in Disease Processes: A Compilation of cause and consequence," Free Radic. Res. Comm., vol. 19, 141, 1995.

[31] B. Auddy, F. Ferreira, L. Blasina, F. Lafon, F. Arredondo, F. Dajas, P.C. Tripathi, T. Seal, B. Mukherjee, "Screening of antioxidant activity of three Indian medicinal plants, traditionally used for the management of neurodegenerative diseases," J Ethnopharmacol., vol. 84, 131-138, 2003.

[32] B. Sagnia, D. Fedeli, R. Casetti, C. Montesano, G. Falcioni, V. Colizzi, "Antioxidant and Anti-inflammatory activities of extracts from Cassia alata, Eleusine indica, Eremomastax speciosa, Carica papaya and Polyscias fulva medicinal plants collected in Cameroon," PLoS One, vol. 9, e103999, 2014.

[33] Cancer Statistics, $\mathrm{http} / / /$ seer.cancer.gov/statfacts/html/colorect.html accessed on Aug, 2014

[34] N. Manojlovic, B. Rankovic, M. Kosanic, P. Vasiljevic, T. Stanojkovic, "Chemical composition of three Parmelia lichens and antioxidant, antimicrobial and cytotoxic activities of some their major metabolites," Phytomedicine, vol. 19, 1166-1172, 2012.

[35] F. Ari, E. Ulukaya, S. Oran, S. Celikler, S. Ozturk, M.Z. Ozel, "Promising anticancer activity of a lichen, Parmelia sulcata Taylor, against breast cancer cell lines and genotoxic effect on human lymphocyte," Cytotechnology, 2014.

[36] K.V. Balan, C. Demetzos, J. Prince, K. Dimas, M. Cladaras, Z. Han, J. H. Wyche, P. Pantazis, "Induction of apoptosis in human colon cancer HCT116 cells treated with an extract of the plant product, chios mastic gum," In Vivo., vol. 19, 93$102,2005$. 